\title{
PENGEMBANGAN MEDIA PEMBELAJARAN PUZZLE PADA MATERI MEMBACA PERMULAAN SISWA KELAS 1 SD NEGERI 77 PRABUMULIH
}

\author{
Tastin $^{1}$, Hani Atus Sholikhah ${ }^{2}$, Sulastri $^{3}$ \\ Dosen UIN Raden Fatah Palembang1, Dosen UIN Raden Fatah Palembang², \\ Mahasiswa UIN Raden Fatah Palembang ${ }^{3}$ \\ Jalan KH. Zainal Abidin Fikry Km 3.5 Palembang \\ Sur-el: tastin_uin@ @adenfatah.ac.id ${ }^{1}$, hani_uin@ radenfatah.ac.id ${ }^{2}$, \\ sulastri@gmail.com ${ }^{3}$
}

Article info

Article history:

Received:30-09-2021

Revised :19-10-2021

Accepted:20-12-2021

Keywords:

Puzzle Learning

Media, Indonesian

Language, Beginning

Reading

Kata Kunci:

Media Pembelajaran

Puzzle, Bahasa

Indonesia, Membaca

Permulaan

\begin{abstract}
A B S T R A C T
This study aims to: Produce reading mateirals which is validm, practical and effective, the method used is the $R \& D$ development method with the tessmer development model which consists of 2 stages, namely: the preliminary stage and the prototyping stage using a formative evaluation flow. Therefore, it can be concluded: (1) The design of puzzle learning media for the initial reading material for grade 1 students at SDN 77 Prabumulih Sumsel can be used to test its validity seen from the assessment at the self-evaluation stage, (2) Produce puzzle learning media on the beginning reading material that valid in score of 92, material expert validation obtained an average score of 98, and linguist validation obtained an average score of 95, (3) Produces puzzle learning media is effective with an average pretest score of 54 while the average post-test score of 89.
\end{abstract}

Penelitian ini bertujuan untuk: menghasilkan media pembelajaran puzzle pada materi membaca permulaan siswa kelas 1 yang praktis dan efektif, metode yang digunakan adalah metode pengembangan $R \& D$ dengan model pengembangan tessmer. Subjek penelitian ini adalah siswa/i kelas 1 SDN 77 Prabumulih Sumsel dengan menggunakan sampel jenuh dimana sampelnya adalah seluruh subjek yang diteliti yaitu sebanyak 25 peserta didik. Hasil penelitian menunjukkan temeua sebagai berikut. (1) Pendesainan media pembelajaran puzzle pada materi membaca permulaan siswa kelas 1 SDN 77 Prabumulih Sumsel dapat digunakan untuk diuji validitasnya dilihat dari penilaian pada tahap self evaluation, (2) Media pembelajaran puzzle pada materi membaca permulaan yang valid dilihat dari angket kevalidan ahli desain diperoleh rata-rata skor 92, validasi ahli materi diperoleh rata-rata skor 98, dan validasi ahli bahasa diperoleh rata-rata skor 95, (3) Media pembelajaran puzzle pada materi membaca permulaan efektif dengan rata-rata skor post test 89. 


\section{JURNAL ILMIAH \\ BINA EDUKASI \\ ISSN 1979-8598 E-ISSN: 2655-8378 \\ http://journal.binadarma.ac.id/index.php/jurnalbinaedukasi \\ Vol. 14, No. 2, Desember 2021, 157 - 168}

\section{PENDAHULUAN}

Undang-undang Sistem Pendidikan Nasional No. 20 Tahun 2003 menyatakan bahwa pendidikan adalah usaha sadar dan terencana untuk mewujudkan suasana belajar dan proses pembelajaran agar peserta didik secara aktif mengembangkan potensi dirinya untuk memiliki kekuatan spiritual keagamaan, pengendalian diri, kepribadian, kecerdasan, akhlak mulia, serta keterampilan yang diperlukan dirinya, masyarakat, bangsa dan negara. Pendidikan pada hakikatnya merupakan suatu upaya menyiapkan manusia agar mampu mandiri, menjadi anggota masyarakat yang berdaya guna untuk ikut serta dalam pembangunan bangsa. Pada era globalisasi seperti ini, pendidikan menghadapi tantangan yang sangat kompleks. Salah satu permasalahan yang dihadapi adalah usaha meningkatkan kualitas manusia agar bisa bersaing dengan negara-negara maju.

Salah satu komponen penting dalam dunia pembelajaran — terutama di Indonesia—adalah materi bahasa Indonesia, salah satunya adalah membaca. Membaca merupakan bagian yang tak terpisahkan dari pembelajaran bahasa, sebagai bagian dari keterampilan reseptif seharusnya ini tidak terallu "menyulitkan" dibanding kemampuan produktif yang harus menghasilkan bahasa (Sholikhah, 2019). Idealnya pembelajaran bahasa Indonesia menjadi pembelajaran yang menyenangkan dan terimplementatif. Namun, faktanya di lapangan dalam pembelajaran bahasa Indonesia di lapangan, masih banyak peserta didik yang belum memahami dan mengimplementasikan dalam kehidupan sehari-hari. Hasil survei yang dilakukan oleh Sholikhah (2018), dari sampel MI/SD yang ada di Kabupaten dan Kota se-Sumatera Selatan, rata-rata hanya $15 \%$ siswa yang menerapkan penggunan bahasa Indonesia dalam praktiknya. Artinya, bahasa Indonesia belum sepenuhnya menjiwa pada peserta didik yang ada di Indonesia, khsuusnya di SD/MI sebagaimana dalam hasil survei ini.

Karenanya, solusi yang dapat ditawarkan adalah dengan mengupayakan bahan ajar yang dapat meningkatkan kemampuan berbahasa peserta didik, tidak hanya dari aspek teori namun juga implementatif. Bahan ajar memiliki peran yang sangat penting dalam meningkatkan kemampuan peserta didik dalam proses pembelajaran. Prastowo (2019), menyampaikan bahwa bahan ajar merupakan komponen esensial yang tidak dapat terlepas dari proses pembelajaran. Dalam hal ini bisa berbentuk materi ajar ataupun media pembelajaran. Sebagaimana temuan penelitian terdahulu yang dilakukan oleh peneliti (Sholikhah, dkk, 2019) dan (Sholikhah dan Handayani, 2020), bahan ajar sangat berperan dalam meningkatkan pemahman peserta didik. Kedua penelitian menunjukkan temuan bahwa adanya bahan ajar berperan sangat penting dalam meningkatkan kemampuan peserta didik memahami materi sekaligus mempraktikkannya. 


\section{JURNAL ILMIAH}

BINA EDUKASI

ISSN 1979-8598 E-ISSN: 2655-8378

http://journal.binadarma.ac.id/index.php/jurnalbinaedukasi

Vol. 14, No. 2, Desember 2021, 157 - 168

Salah satu usaha yang dapat dilakukan oleh guru untuk mengatasi kejenuhan peserta didik agar dapat antusias dan terlibat secara aktif dalam kegiatan pembelajaran dengan merencanakan serta menggunakan media pembelajaran tradisional yang menarik. Media pembelajaran tradisional merupakan media yang tidak memerlukan fasilitas pendukung modern seperti proyektor, sound, laptop dan viewer dalam penggunaannya.

Berdasarkan observasi di lapangan dan melihat fenomena yang ada di SDN 77 Prabumulih ini, peneliti sangat tertarik untuk mengembangkan media puzzle sebagai sarana siswa belajar dan mendukung pembelajaran agar siswa bersemangat karna belajar dengan penggunaan media bermain puzzle. Alasan pengembangan media puzzle ini karena melihat fenomena di sekolah tersebut penggunaan media pembelajaran masih bersifat konvensional, guru masih berfokus pada media buku paket saja dan prestasi membaca siswa kelas 1 masih rendah serta penggunaan media pembelajaran puzzle dapat menarik perhatian siswa dalam pembelajaran.

Media puzzle adalah media pembelajaran berupa potongan-potongan gambar, huruf, kata dan kalimat menjadi satu gambar yang utuh yang melibatkan psikomotorik anak dan penalarannya dalam menyusun puzzle tersebut. Adapun pengembangan media pembelajaran puzzle kata digunakan dalam penelitian ini berbasis manual karena dilihat dari fasilitas sekolah, kondisi sekolah yang belum mampu menggunakan media elektronik dalam belajar. Diharapkan dengan pengembangan media pembelajaran puzzle kata dapat memberikan dampak baik terhadap kemampuan siswa dalam membaca permulaan.

Berdasarkan uraian di atas, peneliti bermaksud untuk melakukan penelitian dengan judul "Pengembangan Media Pembelajaran Puzzle pada Materi Membaca Permulaan Siswa Kelas 1 SDN 77 Prabumulih Sumsel".

\section{METODOLOGI PENELITIAN}

\subsection{Konsep Produk Media Pembelajaran}

Kata "media" berasal dari bahasa latin, merupakan bentuk jamak dari kata "medium". Secara harfiah kata tersebut merupakan arti perantara atau pengantar. Media pembelajaran adalah sarana fisik untuk menyampaikan isi/materi pembelajaran seperti: buku, film, dan video. Adapun menurut beberapa pendapat mendefinisikan media pembelajaran adalah sebagai berikut: Menurut Saraswati (2018), media pembelajaran adalah suatu alat atau media penyalur informasi belajar atau distributor pesan yang akan disampaikan. Media yang digunakan harus 


\section{JURNAL ILMIAH \\ BINA EDUKASI \\ ISSN 1979-8598 E-ISSN: 2655-8378 \\ http://journal.binadarma.ac.id/index.php/jurnalbinaedukasi \\ Vol. 14, No. 2, Desember 2021, 157 - 168}

sesuai dengan tujuan pembelajaran yang akan disampaikan. Menurut Anitah dkk (2019), media pembelajaran merupakan jembatan dari informasi pembelajaran yang disampaikan oleh guru kepada penerima informasi siswa dengan maksud agar informasi-informasi tersebut dapat diterima dan diserap dengan cepat dan tepat sesuai dengan tujuan. Menurut Ali (2020), Media pembelajaran secara umum adalah alat bantu proses belajar mengajar. Segala sesuatu yang dapat dipergunakan untuk merangsang pikiran, perasaan, perhatian dan kemampuan atau keterampilan pembelajar sehingga dapat mendorong terjadinya proses belajar. Jadi, dapat disimpulkan dari beberapa definisi di atas media pembelajaran adalah semua alat yang digunakan untuk menarik perhatian siswa dan merangsang pikiran, perasaan siswa untuk mendorongterciptanya proses belajar yang aktif.

\subsection{Desain Penelitian}

Penelitian ini menggunakan metode penelitian dan pengembangan (R\&D). Penelitian pengembangan (research and development) yaitu metode penelitian yang digunakan untuk menghasilkan produk tertentu dan menguji keefektivannya. Menurut Borg and Gall (dalam Sholikhah, 2020), yang dimaksud dengan model penelitian dan pengembangan adalah " $a$ process used develop and validate educational product". Pengembangan adalah proses yang dilakukan dalam menciptakan sebuah produk yang dapat digunakan dan diuji kevalidannya. Produk yang dikembangkan dalam penelitian ini adalah: Pengembangan Media Pembelajaran Puzzle pada Materi Membaca Permulaan” pada kelas 1 SD. Subjek penelitian ini menggunakan sampel jenuh, yakni keseluruhan dari populasi yang diteliti. Menurut Sugiyono (2020), "Sampel jenuh adalah teknik penentuan sampel dimana anggota populasi dapat digunakan sebagai sampel”. Jadi di sini peneliti meneliti 25 siswa yang dijadikan sampel dari siswa kelas I SDN 77 Prabumulih.

Instrumen penelitian dan pengembangan yang diguanakan, adalah (a) Walkthrough/ wawancara digunakan untuk merevisi media ajar peserta didik berupa komentar dan saran pada tahap expert review;(b) angket yang berisi validasi tiga pakar ahli (ahli bahasa, ahli materi dan ahli desain) serta angket untuk responden peserta didik; (c) tes prestasi dimana peneliti mengetes kemampuan siswa sebelum dan sesudah belajar menggunakan media pembelajaran puzzle.

Desain penelitian dan pengembangan yang digunakan peneliti, yakni desain yang dikembangkan oleh Tessmer bernama evaluasi formatif (formatif evaluation). Adapun alur desain formative evaluation sebagai berikut. 


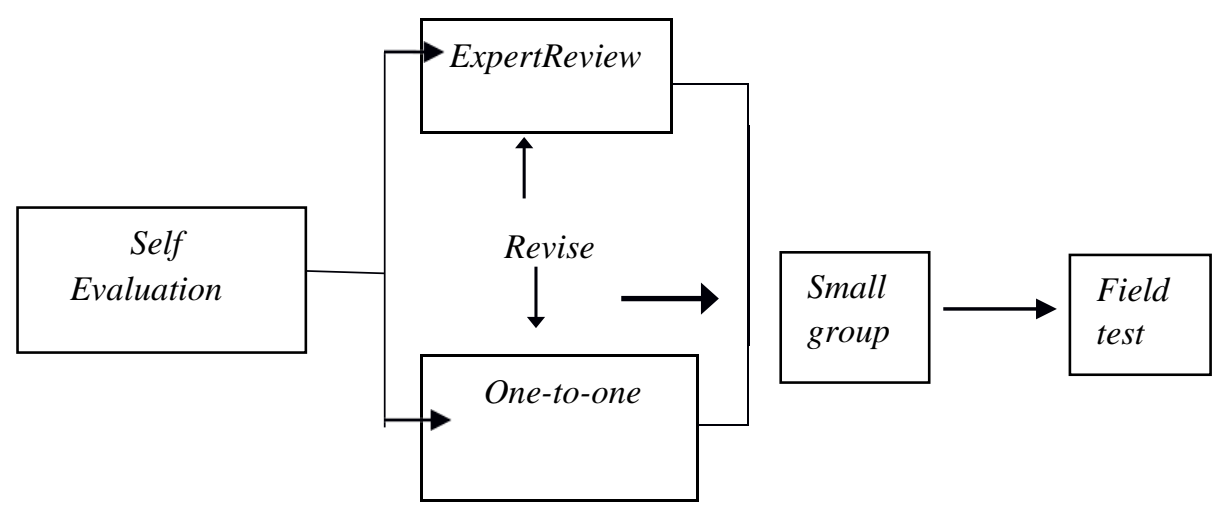

Gambar 1. Alur Desain Evaluasi Formatif Model Tessmer

Langkah-langkah pengembangan media pembelajaran yang digunakan meliputi tahaptahap sebagai berikut.

\section{a. Tahap Preliminary}

Tahapan ini terdiri dari dua tahapan, yaitu tahap persiapan dantahap pendesainan.

1) Tahap Persiapan

Pada tahap ini kegiatan yang dilakukan adalah analisis peserta didik, analisis kurikulum, dan analisis materi. Analisis peserta didik dilakukan untuk mengetahui kemampuan tiap peserta didik dalam pembelajaran Bahasa Indonesia kesulitan peserta didik dalam membaca permulaan, untuk mengetahui subjek penelitian. Analisis kurikulum dilakukan untuk mengetahui kurikulum yang digunakan oleh sekolah yang kelasnya digunakan sebagai subjek penelitian. Analisis materi dilakukan untuk mengetahui materi yang sesuai dengan pengembangan media yang akan peenlitian kembangkan. Analisis materi dilakukan untuk mengetahui Kompetensi Inti (KI) dan Kompetensi Dasar (KD) materi membaca permulaan yang digunakan untuk menyusun RPP, kisi-kisi media ajar.

2) Tahap Pendesainan

Pada tahap ini dilakukan pendesainan media pembelajaran dalam bentuk prototype awal.

\section{b. Tahap Prototyping menggunakan Alur Formative Evaluation}

Tahapan-tahapan pada tahap Prototyping menggunakan alur Formative Evaluation sebagai berikut. 


\section{JURNAL ILMIAH}

BINA EDUKASI

ISSN 1979-8598 E-ISSN: 2655-8378

http://journal.binadarma.ac.id/index.php/jurnalbinaedukasi

Vol. 14, No. 2, Desember 2021, 157 - 168

1) Self Evaluation adalah tahap dimana peneliti mengevaluasi sendiri prototype awal yang telah dikembangkan dengan meminta saran dari teman sejawat sebanyak 3 (tiga) orang dosen sesuai kompetensinya untuk perbaikan prototype awal sehingga dapat diujicoba ke tahap selanjutnya. Hasil revisi pada tahap ini berupa prototype I.

2) Expert Review adalah tahap evaluasi prototype 1 produk pengembangan media puzzle kalimat yang telah didesain dan dievaluasi sendiri oleh peneliti, selanjutnya divalidasi oleh teman sejawat sebanyak 3 (tiga) orang dosen sesuai kompetensinya.

3) One-to-one Evaluation adalah tahap evaluasi prototype I produk pengembangan media pembelajaran puzzle kalimat yang telah divalidasi oleh teman sejawat, selanjutnya di ujicobakan pada seorang peserta didik. Hasil validasi pada tahap expert review dan uji coba pada tahap one-to-one akan digunakan untuk melakukan revisi atau perbaikan prototype I menjadi prototype II.

4) Small Group Evaluation merupakan lanjutan dari evaluasi pada tahap expert review dan one-to-one. Prototype II hasil revisi pada tahap expert rieview dan one-to-one akan di ujicobakan pada kelompok kecil yang terdiri dari 6 orang peserta didik kelas I SD/MI. Peserta didik diminta untuk mengamati, mengerjakan perintah pada prototype II. Kemudian peserta didik diminta untuk mengisi angket kepraktisan untuk mengisi komentarnya mengenai media ajar peserta didik.

5) Field test

Saran-saran serta hasil uji coba pada prototipe kedua dijadikan dasar untuk merevisi instrumen prototipe kedua sehingga diperoleh prototipe ketiga. Hasil revisi diujicobakan ke subjek peneitian dalam hal ini sebagai field test. Pada tahap ini produk yang telah direvisi tadi diujicobakan kepada siswa kelas 1 SDN 77 Prabumulih yang menjadi subjek penelitian. Produk yang diujicobakan pada field test merupakan produk yang telah memenuhi standar validitas, kepraktisan dan keefektifan.

\section{HASIL DAN PEMBAHASAN}

Berikut ini adalah penjabaran tiap-tiap tahap sesuai dengan hasil penelitian yang dilaksanakan. 

77 Prabumulih

Pada tahap ini menentukan desain media pembelajaran, analisis materi dan kurikulum yang sesuai dengan tempat penelitian. Pada tahap self evaluation, peneliti akan melangsungkan evaluasi secara pribadi terhadap prototype awal yang telah dikembangkan. Hasil yang sudah diperbaiki pada tahap ini yaitu prototype I dilanjutkan ke tahap berikutnya expert review.

\subsection{Hasil Kevalidan Media Pembelajaran Puzzle pada Materi Membaca Permulaan Siswa Kelas 1 SDN 77 Prabumulih}

Dalam mengembangkan media pembelajaran puzzle pada materi membaca permulaan siswa kelas 1 SDN 77 Prabumulih yang valid akan melalui tahap alur formative evaluation (expert review). Pada tahapan expert review media pembelajaran akan di evaluasi oleh tiga (3) ahli validator, yang terdiri atas ahli materi, ahli desain, dan ahli bahasa. Untuk penilaian pertama bidang materi, peneliti meminta Umi Suryani, S.Pd. yaitu guru kelas 1 di SDN 77 Prabumulih sebagai validator materi. Adapun yang kedua dalam bidang desain, peneliti meminta Ines Tasya Jadidah, M. Pd. yaitu Dosen PGMI UIN Raden Fatah Palembang sebagai validator desain, dan yang ketiga dalam bidang bahasa peneliti meminta Neneng Juwita, M. Pd. yaitu Dosen MK Bahasa Indonesia UIN Raden Fatah Palembang sebagai validator bahasa. Pengumpulan data pada tahapan ini menggunakan lembar validasi. Setelah mendapat komentar dan saran tentang media pembelajaran, kemudian peneliti melakukan perbaikan atau revisi pada media pembelajaran sehingga dinyatakan valid oleh ketiga ahli di atas.

Validasi desain dilakukan untuk mengetahui kualitas dari desain yang telah dibuat baik dari segi tampilan, daya tarik, dan sebagainya. Validasi Materi dilakukan untuk mengetahui kesesuaian materi dengan kompetensi dasar dan indikator yang digunakan oleh sekolah agar mudah dipahami. Validasi bahasa dilakukan untuk mengetahui kualitas bahasa yang digunakan dalam mengembangkan media pembelajaran, baik dari aspek tingkat perkembangan peserta didik, lugas, komunikatif dan kaidah Bahasa Indonesia yang benar.

Berdasarkan hasil validasi yang dilakukan oleh tiga ahli melalui tahapan expert review ini maka media pembelajaran puzzle pada materi membaca permulaan siswa kelas 1 SDN 77 Prabumulih dapat dikategorikan sangat valid. Berikut ini hasil penilaian lembar angket validasi oleh tiga ahli. 
ISSN 1979-8598 E-ISSN: 2655-8378

http://journal.binadarma.ac.id/index.php/jurnalbinaedukasi

Vol. 14, No. 2, Desember 2021, 157 - 168

Tabel 1. Hasil Validasi Tiga Ahli

\begin{tabular}{llll}
\hline No. & Validator & Skor & Kategori \\
\hline 1. & Bidang desain & 92 & Sangat valid \\
2. & Bidang materi & 98 & Sangat valid \\
3. & Bidang bahasa & 95 & Sangat valid \\
\hline & Rata-rata skor & 95 & Sangat valid
\end{tabular}

\subsection{Hasil Kepraktisan dan Keefektifan Media Pembelajaran Puzzle pada Materi Membaca Permulaan Siswa kelas 1 SDN 77 Prabumulih}

\subsubsection{Hasil Kepraktisan Media Pembelajaran Puzzle pada Materi Membaca Permulaan Siswa kelas 1 SDN 77 Prabumulih}

Tujuan uji kepraktisan terhadap media pembelajaran yang dikembangkan adalah untuk mengetahui tingkat kemudahan dalam memahami dan menggunakan media pembelajaran puzzle yang dikembangkan. Uji kepraktisan respon peserta didik dilakukan dengan memberikan instrumen angket.

Tabel 2. Rekapitulasi hasil kepraktisan peserta didik

\begin{tabular}{llll}
\hline Tahapan & $\begin{array}{c}\text { Jumlah } \\
\text { Respon }\end{array}$ & Rata-rata & Tingkat Kepraktisan \\
\hline One to one & 3 & 98 & Sangat praktis \\
Small group & 6 & 98 & Sangat praktis \\
Field test & 25 & 98 & Sangat praktis \\
\hline Jumlah & & 98 & Sangat praktis \\
\hline
\end{tabular}

Jadi, berdasarkan hasil skor kepraktisan pada tahap responden One to one, Small group, dan Field test maka media pembelajaran puzzle pada materi membaca permulaan dinyatakan praktis dengan 3 tahap kepraktisan diperoleh rata-rata 98 dengan kategori sangat praktis.

\subsubsection{Hasil Keefektifan Media Pembelajaran Puzzle pada Materi Membaca Permulaan Siswa Kelas 1 SDN 77 Prabumulih}

Untuk menguji keefektivan media pembelajaran puzzle pada materi membaca permulaan siswa kelas 1 SDN 77 Prabumulih dilakukan dengan memberikan soal pre test dan post test kepada peserta didik. Tujuan uji keefektifan terhadap media pembelajaran yang dikembangkan adalah untuk mengetahui perbedaan hasil pemahaman sebelum dan sesudah penggunaan media pembelajaran puzzle materi membaca permulaan yang dikembangkan. Ada beberapa tahap yaitu dalam meguji keefektifan sebagai berikut. 


\section{JURNAL ILMIAH}

BINA EDUKASI

ISSN 1979-8598 E-ISSN: 2655-8378

http://journal.binadarma.ac.id/index.php/jurnalbinaedukasi

Vol. 14, No. 2, Desember 2021, 157 - 168

\subsubsection{One to-one}

Berdasarkan hasil lembar soal pre test dan post test one to-one tersebut dapat disimpulkan bahwa ada perbedaan dari sebelum dan sesudah penggunaan media pembelajaran puzzle materi membaca permulaan dimana dari jumlah rata-rata sebelum penggunaan media puzzle adalah 47 dengan kategori cukup efektif sedangkan setelah penggunaan media pembelajaran puzzle siswa dapat mengerjakan soal post test dan mendapatkan rata-rata skor 86 dengan kategori sangat efektif.

\subsubsection{Small Group}

Berdasarkan hasil pretest dan post test peserta didik tersebut dapat disimpulkan bahwa media pembelajaran puzzle materi membaca permulaan pada siswa kelas 1 SDN 77 Prabumulih berpengaruh terhadap hasil belajar peserta didik dengan rata-rata skor pre test 60 sedangkan rata-rata skor post test 90 dengan kategori sangat efektif.

\subsubsection{Field Test}

Berdasarkan hasil pretest dan post test peserta didik tersebut dapat disimpulkan bahwa media pembelajaran puzzle materi membaca permulaan pada siswa kelas 1 SDN 77 Prabumulih sangat berpengaruh terhadap hasil belajar peserta didik dengan rata-rata skor pre test 54 sedangkan rata-rata skor post test 93 dengan kategori sangat efektif.
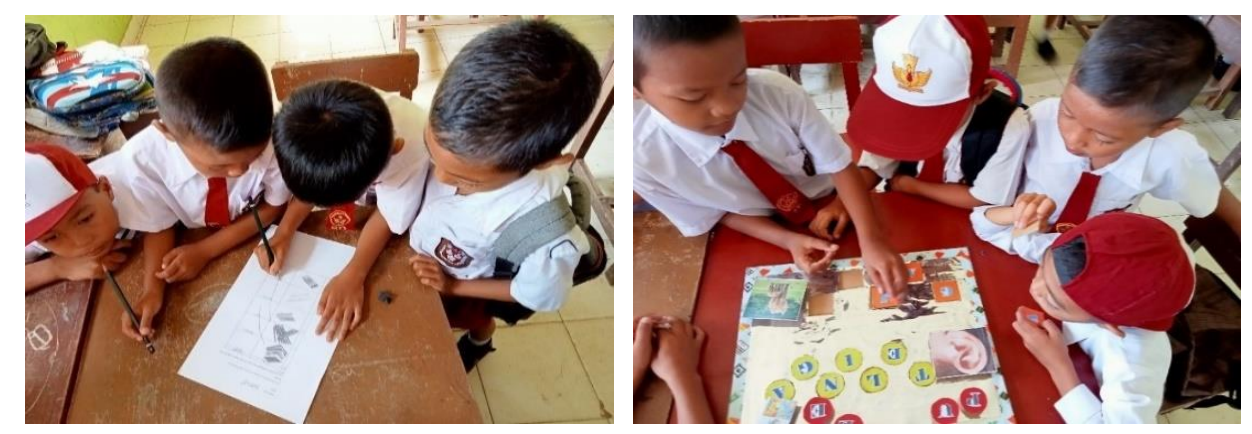

Gambar 2.

Kegiatan peserta didik mengisi angket dan bermain puzzle huruf

Hasil analisis lembar soal pre test dan post test pada tahap field test yang diisi oleh seluruh kelas 1 berjumlah 25 orang peserta didik. Berdasarkan hasil jawaban peserta didik dari sebelum dan sesudah penggunaan media pembelajaran didapatkan perbedaan dari sebelum penggunaan media pembelajaran memperoleh skor rata-rata dari tiga tahap diatas memperoleh rata-rata 54 dengan kategori cukup efektif, sedangkan setelah penggunaan media pembelajaran puzzle peserta didik mampu menjawab lembar soal post test dengan skor rata-rata 89 dengan 


\section{JURNAL ILMIAH}

BINA EDUKASI

ISSN 1979-8598 E-ISSN: 2655-8378

http://journal.binadarma.ac.id/index.php/jurnalbinaedukasi

Vol. 14, No. 2, Desember 2021, 157 - 168

kategori sangat efektif. Berikut merupakan hasil rekapitulasi ketiga tahap keefektivan media pembelajaran puzzle.

Tabel 3. Rekapitulasi hasil keefektivan peserta didik

\begin{tabular}{lllll}
\hline Tahapan & \multicolumn{1}{c}{$\begin{array}{c}\text { Jumlah } \\
\text { Responden }\end{array}$} & $\begin{array}{c}\text { Rata-rata } \\
\text { Pre Test }\end{array}$ & $\begin{array}{c}\text { Rata-rata } \\
\text { Post Test }\end{array}$ & Tingkat Keefektifan \\
\hline One to one & 3 & 47 & 86 & angat efektif \\
Small group & 6 & 60 & 90 & angat efektif \\
Field test & 25 & 54 & 93 & angat efektif \\
\hline
\end{tabular}

\section{SIMPULAN}

Bersumber pada hasil penelitian mengenai pengembangan media pembelajaran puzzle pada materi membaca permulaan siswa kelas 1 SDN 77 Prabumulih, maka dapat disimpulkan sebagai berikut.

1. Pendesainan/perancangan media pembelajaran puzzle pada materi membaca permulaan siswa kelas 1 SDN 77 Prabumulih dapat digunakan untuk diuji validitas yang dilaksanakan pada tahap expert review. Hal ini terlihat dari penilaian pada tahap self evaluation berupa komentar dan saran yang digunakan peneliti untuk merevisi media pembelajaran untuk dijadikan prototype I sehingga dapat diuji validitasnya pada tahap berikutnya.

2. Media pembelajaran puzzle pada materi membaca permulaan siswa kelas 1 SDN 77 Prabumulih terkategori sangat valid. Hal ini terlihat dari penilaian hasil angket validasi yang dilakukan pada tahap expert review memperoleh rata-rata skor 95 . Dengan demikian, maka dapat dikatakan bahwa media pembelajaran puzzle yang dikembangkan memenuhi kriteria sangat valid.

3. Media pembelajaran puzzle pada materi membaca permulaan siswa kelas 1 SDN 77 Prabumulih terkategori sangat praktis dan sangat efektif. Hal ini terlihat dari penilaian hasil angket kepraktisan dengan skor rata-rata pada responden peserta didik tahap one to-one memperoleh rata-rata skor 98 dengan kategori sangat praktis dan tahap small group memperoleh skor 98 dengan kategori sangat praktis, dan tahap terakhir field test juga mendapat rata-rata 98 dengan kategori sangat praktis. Dengan demikian, maka dapat dikatakan bahwa media pembelajaran puzzle yang dikembangkan tersebut memenuhi kriteria sangat praktis.

4. Dan Media pembelajaran puzzle pada materi membaca permulaan siswa kelas 1 SDN 77 Prabumulih terkategori sangat efektif. Hal ini terlihat dari perbedaan hasil nilai atau skor yang didapatkan oleh peserta didik. Pada tahap one to-one peserta didik mendapatkan skor rata-rata pre test 47 sedangkan pada soal post test peserta didik 


\section{JURNAL ILMIAH}

BINA EDUKASI

ISSN 1979-8598 E-ISSN: 2655-8378

http://journal.binadarma.ac.id/index.php/jurnalbinaedukasi

Vol. 14, No. 2, Desember 2021, 157 - 168

mendapatkan skor rata-rata 86 dengan kategori sangat efektif. Dan untuk tahap small group peserta didik mendapatkan skor rata-rata pre test 60 sedangkan pada soal post test peserta didik mendapatkan skor 90 dengan kategori sangat efektif, serta untuk tahap field test peserta didik mendapatkan skor rata-rata 54 dengan kategori cukup efektif sedangkan pada soal post test peserta didik memperoleh skor rata-rata 93 dengan kategori sangat efektif.

Dengan demikian, maka dapat dikatakan bahwa dengan adanya penggunaan media pembelajaran puzzle yang dikembangkan tersebut dapat meningkatkan hasil belajar siswa dan memenuhi kriteria sangat efektif.

\section{DAFTAR PUSTAKA}

Ali, Kemas Mas’ud.2020. Media Pembelajaran. Palembang: Rafa Press.

Anitah, Banun dkk. 2019. Media Pembelajaran Kontemporer. Palembang: KSM Press.

Fitria, Siska Eka. Analisis Factor Kondisi Ekonomi, Tingkat Pendidikan dan Kemampuan Berwirausaha Terhadap Kinerja Usaha Bagi Pengusaha Pandang di Desa Cukanggenteng. Jurnal Manajemen Indonesia. 2018, 18 (3).

Prastowo, Andi. 2018. Panduan Kreatif Membuat Bahan Ajar Inovatif. Jakarta: Gramedia.

Saraswati, Dewi . 2018. The Developing Of Tematik Teaching Media Magic Puzzle Theme Of "Berbagi Pekerjaan" In Fourth Grade Of Primary School. Jurnal Pendidikan Dasar Nusantara, (4) 1 ISSN 2460-6324.

Samiha, Yulia Tri. 2020. "Desain Pengembangan Bahan Ajar IPS MI Berbasis Kearifan Lokal." Jurnal JIP PGMI.

Sholikhah, Hani Atus. 2018. Pengembangan Desain Pembelajaran Berbasis Reasoning Analysis pada MK Metodologi Bahasa Indonesia MI. Jurnal Primary. Banten:IAIN Banten.

Sholikhah, Hani Atus. 2019. Stukturalisme Bahasa: Teori dan Implementai. Palembang: KSM Press.

Sholikhah, Hani Atus dan Tutut Handayani. 2020. "Pengembangan Bahan Ajar MK Materi Bahasa Indonesia MI Berbasis Pendekatan Struktural”. Palembang: LP2M UIN Raden Fatah. 


\section{JURNAL ILMIAH}

BINA EDUKASI

ISSN 1979-8598 E-ISSN: 2655-8378

http://journal.binadarma.ac.id/index.php/jurnalbinaedukasi

Vol. 14, No. 2, Desember 2021, 157 - 168

Sholikhah, Hani Atus dkk. 2020. "Bahan Ajar Materi Bahasa Indonesia MI Berbasis Pendekatan Struktural”. Jurnal Sajie, IAIN Samarinda.

Sholikhah, Hani Atus dan Tutut Handayani. 2020.Pengembangan Bahan Ajar Metodologi Pembelajaran Bahasa Indonesia di PGMI FITK UIN Raden Fatah Palembang. Jurnal Ilmiah Bina Edukasi 13, no 2.

Sugiyono. 2020. Metode PenelitianKuantitatid, Kualitatif, dan R\&D. Jakarta: Alfabeta. 